\title{
PENGEMBANGAN BAHAN AJAR MATEMATIKA DASAR LAYANAN JURUSAN NON EKSAK
}

\author{
Finola Marta Putri \\ UIN Syarif Hidayatullah Jakarta \\ finola.marta@uinjkt.ac.id
}

\begin{abstract}
Abstrak
Penelitian ini merupakan metode penelitian dan pengembangan yaitu metode penelitian yang digunakan untuk menghasilkan produk tertentu. Tujuan penelitian ini adalah menghasilkan produk berupa bahan ajar Matematika Dasar Layanan seperti yang sesuai untuk diterapkan pada Jurusan Non Eksak. Teknik pengumpulan data berupa lembar kuesioner untuk mahahasiswa mengenai bahan ajar yang telah digunakan selama ini dan angket untuk dosen sebagai validator yang digunakan untuk memvalidasi produk (bahan ajar) yang telah peneliti hasilkan. Penelitian ini menghasilkan produk berupa bahan ajar Matematika Dasar Layanan yang yang sesuai dengan permintaan mahasiswa untuk diterapkan pada Jurusan Non Eksak yaitu bahan ajar yang memuat lebih banyak contoh soal, sehingga mahasiswa dapat mengerjakan latihan soal yang serupa dan apabila diberikan soal yang kemampuannya lebih tinggi maka diharapkan dapat meningkatkan kemampuan pemahaman konsep matematis mahasiswa.
\end{abstract}

Kata kunci: Metode Penelitian dan Pengembangan, Bahan Ajar

\section{PENDAHULUAN}

Matematika merupakan ilmu universal yang mendasari perkembangan teknologi modern, mempunyai peran penting dalam berbagai disiplin ilmu dan melatih daya pikir manusia. Menurut Badan Standar Nasional Pendidikan pelajaran matematika perlu diberikan kepada semua peserta didik mulai dari sekolah dasar untuk membekali peserta didik dengan kemampuan berpikir logis, analitis, sistematis, kritis, dan kreatif, serta kemampuan bekerjasama. Oleh sebab itu, maka sepatutnya diberikan perhatian yang lebih besar terhadap pembelajaran matematika untuk setiap jenjang pendidikan (Putri, 2009).

Mata kuliah Matematika Dasar merupakan mata kuliah wajib pada hampir semua Program Studi di Fakultas Ilmu Tarbiah dan Keguruan Universitas Islam Negeri Syarif 
Hidayatullah Jakarta. Mata kuliah ini merupakan konsep dasar matematika sehingga diharapkan para mahasiswa mampu menyusun deduksi dan berpikir secara sitematis. Oleh karena itu, sudah sewajarnya dosen harus mampu melakukan perbaikan-perbaikan mutu perkuliahan yang pada akhirnya diharapkan dapat meningkatkan hasil belajar matematika mahasiswa. Agar belajar dapat memperoleh hasil yang optimal, maka lingkungan belajar pun harus ikut mendukung. Berdasarkan Vygotsky (Suryadi, 2007: 721) yang menyatakan bahwa lingkungan belajar hendaknya diciptakan sesuai dengan kebutuhan siswa dalam belajar. Terciptanya lingkungan belajar yang baik dapat membantu siswa dalam mencapai perkembangan potensialnya. Selain itu, menurut Hermawan, dkk (2007: 65) yang dikembangkan dari pendapat Hilna Taba mengemukakan bahwa ketika siswa berpikir, maka secara psikologis harus didukung oleh faktor ketenangan dalam hal emosi, dan selanjutnya anak akan bisa memahami dan mempelajari pengetahuan baru tersebut dengan menggunakan logikanya. Oleh karena itu, pendidik harus mampu menciptakan kondisi kelas yang dinamis sehingga diharapkan dapat memperbaiki mutu belajar. Pada tingkat perguruan tinggi, dosen sebagai fasilitator dan motivator memegang peranan penting dalam upaya memperbaiki mutu perkuliahan.

Pengalaman peneliti sebagai pengajar dalam perkuliahan Matematika Dasar Jurusan Non Eksak yaitu sulitnya mahasiswa memahami materi. Salah satu penyebabnya yaitu buku pedoman yang ada merupakan buku umum yaitu untuk jurusan eksak sehingga mahasiswa jurusan non eksak agak sulit untuk memahami materi pembelajaran yang diberikan. Hal ini dikarenakan tingkat berpikir matematisnya berbeda sehingga jika diberikan contoh soal yang berupa pengembangan, mereka sulit memahaminya. Penyebab lain adalah pengetahuan tentang istilah-istilah dalam matematika yang kurang familiar di lingkungan belajar mereka sehingga pengembangan bahan ajar yang sesuai dengan latar belakang pendidikan (jurusan non eksak) perlu dilakukan sehingga diharapkan hasil belajar mahasiswa lebih optimal. Hal ini juga diperkuat oleh Kristian, dkk (2016: 203) yang menyatakan bahwa bahan ajar memiliki peranan yang penting dalam pembelajaran. Bahan ajar memiliki kedudukan penting yakni sebagai pusat pembelajaran dan berfungsi sebagai alat pembelajaran yang strategis bagi guru dan siswa. Pengembangan bahan ajar diperlukan untuk mempersiapkan kegiatan pembelajaran dalam berbagai situasi. Pengembangan bahan ajar juga diperlukan untuk menciptakan kelangsungan kegiatan pembelajaran dengan kegiatan-kegiatan yang inovatif dan penuh daya tarik. Tujuan pengembangan bahan ajar adalah untuk mempersiapkan kelangsungan kegiatan pembelajaran yang selalu diisi dengan bahan-bahan yang selalu baru, ditampilkan dengan cara baru, dan disiasati dengan strategi yang baru pula. 
Metode penelitian dan pengembangan atau dalam bahasa Inggrisnya Research and Development adalah metode penelitian yang digunakan untuk menghasilkan produk tertentu, dan menguji keefektifan produk tersebut. Untuk dapat menghasilkan produk tertentu digunakan penelitian yang bersifat analisis kebutuhan dan untuk menguji keefektifan produk tersebut supaya dapat berfungsi di masyarakat luas, maka diperlukan penelitian untuk menguji keefektifan produk tersebut. Jadi, penelitian dan pengembangan bersifat longitudinal (bertahap bisa multi years) (Sugiyono, 2015a: 407). Penelitian ini yang didanai oleh BOPTN DIPA APBN UIN Syarif Hidayatullah Jakarta adalah penelitian yang mengahasilkan produk sehingga metode yang digunakan adalah metode penelitian dan pengembangan.

Penelitian dan pengembangan berfungsi untuk memvalidasi dan mengembangkan produk. Memvalidasi produk berarti produk itu telah ada, dan peneliti hanya menguji efektivitas atau validitas produk tersebut. Mengembangkan produk dalam arti yang luas dapat berupa memperbarui produk yang telah ada (sehingga menjadi lebih praktis, efektif, dan efisien) atau menciptakan produk baru (yang sebelumnya belum pernah ada) Sugiyono (2015b: 28). Selanjutnya, Sugiyono (2015a: 408) juga mengemukakan bahwa penelitian dan pengembangan yang menghasilkan produk tertentu untuk bidang administrasi, pendidikan, dan sosial lainnya masih rendah. Padahal banyak produk tertentu dalam bidang pendidikan dan sosial yang perlu dihasilkan melalui research and development.

Sukmadinata (dalam Haryati, 2012: 14) mengemukakan bahwa penelitian dan pengembangan merupakan pendekatan penelitian untuk menghasilkan produk baru atau menyempurnakan produk yang telah ada. Produk yang dihasilkan bisa berbentuk software, ataupun hardware seperti buku, modul, paket, program pembelajaran ataupun alat bantu belajar. Penelitian dan pengembangan berbeda dengan penelitian biasa yang hanya menghasilkan saran-saran bagi perbaikan, penelitian dan pengembangan menghasilkan produk yang langsung bisa digunakan.

Berdasarkan uraian dia atas, maka peneliti mencoba untuk mengembangkan bahan ajar matematika dasar layanan jurusan non eksak. Oleh karena itu, peneliti tertarik untuk melakukan penelitian dengan judul Pengembangan Bahan Ajar Matematika Dasar Layanan Jurusan Non Eksak.

Rumusan masalah dalam penelitian ini adalah bahan ajar matematika dasar layanan seperti apakah yang sesuai untuk diterapkan pada Jurusan Non Eksak?

Penelitian ini bertujuan untuk menghasilkan produk berupa bahan ajar Matematika Dasar Layanan yang sesuai untuk diterapkan pada Jurusan Non Eksak. 
Manfaat penelitian ini diharapkan memberikan beberapa kontribusi bagi peningkatan mutu pembelajaran matematika dasar layanan jurusan non eksak, baik dari sisi mahasiswa maupun sisi dosen. Bagi mahasiswa, penelitian ini diharapkan mampu meningkatkan pemahaman mahasiswa jurusan non eksak terhadap mata kuliah matematika dasar. Bagi dosen, produk pelaksanaan hibah penelitian ini diharapkan dapat menjadi acuan bahan ajar bagi dosen-dosen yang mengampu mata kuliah matematika dasar layanan jurusan non eksak.

\section{METODE PENELITIAN}

Metode yang digunakan dalam penelitian ini adalah metode penelitian dan pengembangan atau dalam bahasa Inggrisnya Research and Development, yaitu metode penelitian yang digunakan untuk menghasilkan produk tertentu, dan menguji keefektifan produk tersebut. Untuk dapat menghasilkan produk tertentu digunakan penelitian (basic research) yang bersifat analisis kebutuhan dan untuk menguji keefektifan produk tersebut supaya dapat berfungsi di masyarakat luas, maka diperlukan penelitian (applied research) untuk menguji keefektifan produk tersebut. Jadi penelitian dan pengembangan bersifat longitudinal (bertahap bisa multi years) (Sugiyono, 2015a). Oleh sebab itu, Sugiyono (2015b) juga mengemukakan bahwa penelitian dan pengembangan sering disebut "jembatan" antara basic research dengan applied research dan dapat digambarkan seperti gambar berikut.

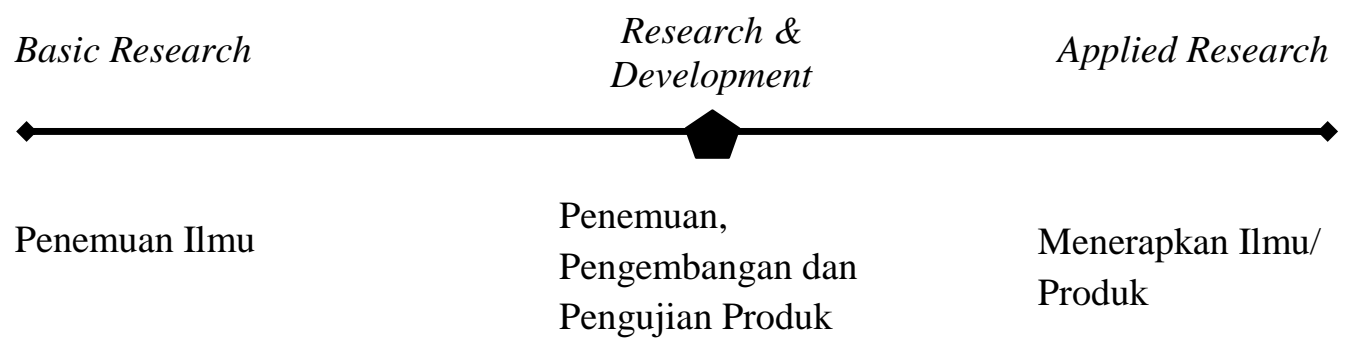

\section{Gambar 1. Penelitian dan Pengembangan Merupakan “Jembatan” Antara Basic Research dan Applied Research}

Langkah-langkah penelitian dan pengembangan menurut Sugiyono (2015a) sebagai berikut.

1. Potensi dan masalah

Data tentang potensi dan masalah tidak harus dicari sendiri, tetapi bisa berdasarkan laporan penelitian orang lain, atau dokumentasi laporan kegiatan dari perorangan atau instansi tertentu yang masih up to date.

2. Mengumpulkan informasi 
Setelah langkah di atas dilakukan, maka perlu dikumpulkan berbagai informasi yang dapat digunakan sebagai bahan untuk perencanaan produk tertentu yang diharapkan dapat mengatasi masalah tersebut.

3. Desain produk

Dalam bidang pendidikan, produk-produk yang dihasilkan melalui penelitian R\&D diharapkan dapat meningkatkan produktivitas pendidikan, yaitu lulusan yang jumlahnya banyak, berkualitas, dan relevan dengan kebutuhan. Produk-produk pendidikan misalnya kurikulum yang spesifik untuk keperluan pendidikan tertentu, metode mengajar, media pendidikan, buku ajar, modul, kompetensi tenaga kependidikan, dan lain-lain.

Hasil akhir dari kegiatan penelitian dan pengembangan adalah berupa desain produk baru, yang lengkap dengan spesifikasinya. Desain penelitian ini masih bersifat hipotetik. Dikatakan hipotetik karena efektivitasnya belum terbukti, dan akan dapat diketahui setelah melalui pengujian-pengujian. Desain produk harus diwujudkan dalam gambar atau bagan, sehingga dapat digunakan sebagai pegangan untuk menilai dan membuatnya.

4. Validasi desain

Validasi desain merupakan proses kegiatan untuk menilai apakah rancangan produk secara rasional akan lebih efektif dari yang lama atau tidak. Dikatakan secara rasional karena validasi di sini masih bersifat penilaian berdasarkan pemikiran rasional, belum fakta lapangan.

5. Perbaikan desain

Setelah divalidasi, akan diketahui kelemahannya. Kelemahan tersebut dicoba untuk dikurangi dengan cara memperbaiki desain.

6. Uji coba produk

Untuk pengujian dapat dilakukan eksperimen, yaitu membandingkan efektivitas dan efisiensi sistem kerja lama dengan yang baru.

7. Revisi produk

Jika hasil uji coba kurang memuaskan, maka desain produk perlu direvisi lagi. Stelah direvisi, maka perlu diujicobakan lagi pada kerja yang sesungguhnya.

8. Ujicoba pemakaian

Setelah pengujian terhadap produk berhasil, dan mungkin ada revisi yang tidak terlalu penting, maka selanjutnya produk yang berupa sistem kerja baru tersebut diterapkan dalam kondisi nyata untuk lingkup yang luas. Dalam operasinya sistem 
kerja baru tersebut tetap harus dinilai kekurangan atau hambatan yang muncul guna untuk perbaikan lebih lanjut.

9. Revisi produk

Revisi produk ini dilakukan apabila dalam pemakaian kondisi nyata terdapat kekurangan dan kelemahan. Dalam uji pemakaian, sebaiknya pembuat produk selalu mengevaluasi bagaimana kinerja produk.

10. Pembuatan produk masal

Pembuatan produk masal ini dilakukan apabila produk yang telah diujicobakan dinyatakan efektif dan layak untuk diproduksi masal.

Langkah penelitian dan pengembangan yang peneliti lakukan dalam penelitian ini hanya sampai langkah 4. Hal ini disebabkan keterbatasan-keterbatasan yang peneliti miliki.

Teknik pengumpulan data dalam penelitian ini berupa lembar kuesioner untuk mahahasiswa mengenai bahan ajar yang telah digunakan selama ini dan angket untuk dosen sebagai validator yang digunakan untuk memvalidasi produk (bahan ajar) yang telah peneliti hasilkan.

Data yang dianalisis yaitu data kualitatif deskriptif berupa lembar kuesioner untuk mahasiswa dan angket untuk dosen validator.

\section{HASIL DAN PEMBAHASAN}

\section{Deskripsi Data}

a. Deskripsi lembar kuesioner mahasiswa

Data yang diperoleh dari lembar kuesioner mahasiswa terdiri dari dua buah pertanyaan untuk setiap materi. Pada soal nomor satu yang berbunyi "Bagaimana tanggapan anda tentang bahan ajar/buku pedoman matematika dasar", rata-rata mahasiswa menjawab bahwa bahan ajar sudah baik. Namun, pada soal nomor dua yang berbunyi "Berilah kritik dan saran untuk perbaikan bahan ajar/buku pedoman matematika dasar", rata-rata mahasiswa menjawab bahwa kurangnya contoh soal, sehingga sering didapati latihan soal yang tidak ada contoh soal serupa sebelumnya.

b. Deskripsi angket validasi dosen

Setelah peneliti membuat bahan ajar yang sesuai dengan keinginan mahasiswa, maka peneliti meminta rekan sejawat yaitu dosen Pendidikan Matematika untuk memvalidasi produk penelitian ini yaitu bahan ajar matematika dasar layanan jurusan 
non eksak. Berdasarkan hasil angket validasi, diketahui bahwa bahan ajar yang telah peneliti hasilkan telah sesuai dengan keinginan mahasiswa.

\section{Pembahasan Hasil Penelitian}

a. Lembar kuesioner mahasiswa

Hasil kuesioner mahasiswa untuk soal nomor satu pada semua materi rata-rata menjawab bahwa bahan ajar matematika sudah baik, tetapi pada saat diminta untuk memberikan kritik dan saran untuk perbaikan bahan ajar/buku pedoman matematika dasar rata-rata mereka menjawab bahwa kurangnya contoh soal, sehingga sering didapati latihan soal yang tidak ada contoh soal serupa sebelumnya.

Berdasarkan hasil jawaban soal nomor dua diketahui bahwa kemampuan pemahaman konsep matematis mahasiswa masih belum optimal. Karena jika mereka memahami konsep, maka mereka seharusnya dapat menyelesaikan solusi dari soal-soal yang telah diberikan. Hal ini juga disebabkan karena latar belakang mereka yaitu jurusan non eksak sehingga kemampuan matematisnya berbeda dengan kemampuan matematis mahasiswa jurusan eksak. Berdasarkan pendapat Vygotsky (Suryadi, 2007: 721) yang menyatakan bahwa lingkungan belajar hendaknya diciptakan sesuai dengan kebutuhan siswa dalam belajar, yang dimaksud dalam penelitian ini yaitu bahan ajar matematika dasar yang sesuai dengan kebutuhan mahasiswa jurusan non eksak. Oleh karena itu, sudah sewajarnya pengembangan bahan ajar matematika dasar khusus untuk jurusan non eksak disediakan.

b. Angket validasi dosen

Berdasarkan hasil angket validasi, diketahui bahwa bahan ajar yang telah peneliti hasilkan telah sesuai dengan keinginan mahasiswa. Hal ini terlihat dari butir soal angket yang pertama yang berbunyi "bahan ajar mengkondisikan mahasiswa untuk menganalisis berbagai fenomena dan peristiwa sehari-hari untuk membangun pemahamannya tentang konsep" telah dipenuhi dengan cara penanaman konsep melalui contoh dalam kehidupan nyata.

Butir soal angket yang kedua berbunyi "Bahan ajar dapat mengarahkan mahasiswa untuk membangun konsep yang akan dipelajari”, juga telah dipenuhi dengan cara penekanan penulisan pada konsep-konsep materinya. Butir ketiga dan keempat yang berbunyi "Bahan ajar menyampaikan konsep dengan memberikan contoh-contoh soal yang dapat mengarahkan siswa untuk membangun pemahamannya, dan bahan ajar mengajak mahasiswa untuk mengidentifikasi hubungan antara berbagai konsep. 
Konsep-konsep tersebut diperoleh dari berbagai kegiatan pembelajaran yang ada pada bahan ajar" juga telah peneliti penuhi.

Butir soal kelima yang berbunyi "Bahan ajar mengajak mahasiswa untuk menarik kesimpulan dari berbagai pernyataan yang ada dalam bahan ajar" juga telah peneliti penuhi, misalnya dengan cara menentukan himpunan penyelesaian pertidaksamaan dari diagram garis yang telah diperoleh. Butir soal keenam yang berbunyi "Bahan ajar melatih mahasiswa membuat keputusan (solusi) berdasarkan kajian mendalam dari bukti-bukti empiris yang ada" juga telah peneliti penuhi dengan cara membuat soal yang berupa pemecahan masalah.

"Bahan ajar mengkondisikan mahasiswa untuk menjawab soal yang telah diajukan, berdasakan hasil penyelesaian yang telah dikerjakan”. Butir soal ini juga telah peneliti penuhi dengan cara memperbanyak contoh soal sehingga mahasiswa dapat menjawab soal-soal yang serupa dan diaharapkan pemahaman konsepnya pun meningkat.

Butir soal terakhir yang berbunyi "Bahan ajar berisi pertanyaan-pertanyaan yang menuntun mahasiswa untuk mendefinisikan dan memberikan istilah", juga telah peneliti penuhi. Jadi, bahan ajar yang peneliti buat telah sesuai dengan tujuan penelitian ini yaitu menghasilkan produk berupa bahan ajar Matematika Dasar Layanan yang sesuai untuk diterapkan pada Jurusan Non Eksak yaitu bahan ajar yang sesuai dengan permintaan mahasiswa dengan cara memperbanyak contoh soal, sehingga mahasiswa dapat mengerjakan latihan soal yang serupa dan apabila diberikan soal yang kemampuannya lebih tinggi maka diharapkan dapat meningkatkan kemampuan pemahaman konsep matematis mahasiswa.

\section{SIMPULAN DAN SARAN}

Bahan ajar yang peneliti buat telah sesuai dengan tujuan penelitian ini yaitu menghasilkan produk berupa bahan ajar Matematika Dasar Layanan yang sesuai untuk diterapkan pada Jurusan Non Eksak yaitu bahan ajar yang sesuai dengan permintaan mahasiswa dengan cara memperbanyak contoh soal, sehingga mahasiswa dapat mengerjakan latihan soal yang serupa dan apabila diberikan soal yang kemampuannya lebih tinggi maka diharapkan dapat meningkatkan kemampuan pemahaman konsep matematis mahasiswa.

Saran dari penelitian ini yaitu: 
a. Jika mengajar, maka sebaiknya menggunakan bahan ajar khusus yang sesuai dengan kemampuan peserta didik tersebut sehingga diharapkan dapat mengoptimalkan hasil belajar.

b. Penelitian ini dapat dilanjutkan dengan cara melakukan langkah lima sampai selesai sesuai dengan langkah R\&D oleh Sugiyono.

\section{DAFTAR PUSTAKA}

Kristian, N., Suyono., dan Sunaryo. (2016). "Pengembangan Bahan Ajar Menulis Laporan Penelitian Berbasis Pengayaan Skemata Bacaan", dalam Jurnal Pendidikan: Teori, Penelitian, dan Pengembangan. [Online]. Tersedia: http://journal.um.ac.id/plugins/generic/pdfJsViewer/pdf.js/build/pdf.worker.js. [16 Juli 2016].

Haryati. (2012). Research and Development $(R \& D)$ sebagai Salah Satu Model Penelitian dalam Bidang Pendidikan. Artikel. [Online]. Tersedia: $\mathrm{http} / /$ download.portalgaruda.org/article.php?article $=60637 \&$ val=4518\&title=. [14 Maret 2015].

Hermawan, AH., Deni, D., Didi, S., dan Dinn, W. (2007). “Teori Mengajar”, dalam Ilmu dan Aplikasi Pendidikan. Bandung: Pedagogiana Press.

Putri, FM. (2009). “Aktivasi Multiple Intelligences dalam Pembelajaran Kooperatif Pendekatan Struktural Think Pair Square untuk Meningkatkan Hasil Belajar Matematika Siswa Kelas VIII 1 SMP Negeri 21 Pekanbaru”. Skripsi Universitas Riau.

Sugiyono. (2015a). Metode Penelitian Pendidikan Pendekatan Kuantitatif, Kualitatif dan $R \& D$. Bandung: Penerbit Alfabeta.

Sugiyono. (2015b). Metode Penelitian dan Pengembangan Reseach and Development. Bandung: Penerbit Alfabeta.

Suryadi, D. (2007). "Pendidikan Matematika", dalam Ilmu dan Aplikasi Pendidikan. Bandung: Pedagogiana Press.

\section{UCAPAN TERIMAKASIH}

Alhamdulillaahirabbil'aalamiin, puji dan syukur peneliti ucapkan kepada Allah SWT. karena peneliti telah dapat menyelesaikan sebuah karya tulis (penelitian ilmiah) yang berjudul " Pengembangan Bahan Ajar Matematika Dasar Layanan Jurusan Non Eksak". Pada penelitian ini peneliti telah menghasilkan produk berupa bahan ajar Matematika Dasar Layanan yang sesuai untuk diterapkan pada Jurusan Non Eksak dan diharapkan dapat menjadi acuan bagi rekan dosen lainnya yang juga mengampu mata kuliah matematika dasar layanan. Tidak lupa pula peneliti juga ingin mengucapkan terimakasih atas bantuan dana hibah BOPTN DIPA APBN UIN Syarif Hidayatullah Jakarta, karena dengan adanya bantuan dana ini sangat membantu peneliti dalam segi finansial sehingga peneliti lebih termotivasi lagi dalam pembuatan karya tulis ilmiah ini. 